\title{
Lagrangian Investigation on the Compound Effects of Reclamation and Proposed Tidal Barrage to the Environmental Flow
}

\author{
(Kajian Lagrangian Terhadap Gabungan Kesan Tambakan dan Cadangan Pintu Kawalan \\ Air Pasang-Surut Terhadap Aliran Alam Sekitar) \\ Wei-Koon Lee* \& Nur Hidayah Aqilla Zaharuddin
}

ABSTRACT

\begin{abstract}
Large-scale reclamation at Tekong Island, Singapore and the construction of a tidal barrage across Johor River in Kota Tinggi is expected to alter the local hydrodynamics in Johor River Estuary (JRE) and East Tebrau Strait (ETS). Using flow field generated from a set of hyperbolic shallow water equations solved on hierarchical quadtree grid system, Lagrangian particle tracking is performed to examine the individual and combined effects of the above developments on particle fate. Results show that particle escape is highly dependent on the tidal cycle and the initial positions. Stretching of particles is observed in all cases, whereas dispersion occurs only in ETS. While the flushing effect in JRE is enhanced after the completion of the above projects, the resident time of particles released in the ETS increases, suggesting potential environmental threat to the already polluted water body.
\end{abstract}

Keywords: Johor Estuary; Langrangian tracking; Tebrau Strait; Tekong Island

ABSTRAK

Tambakan besar-besaran di Pulau Tekong, Singapura dan pembinaan pintu kawalan air pasang-surut di Sungai Johor dekat Kota tinggi dijangka akan mengubah hidrodinamik sekitar Muara Sungai Johor dan bahagian timur Selat Tebrau. Dengan mengunakan peta aliran hasil daripada penyelesaian satu set persamaan hiperbolik aliran cetek dalam sistem grid berhierarki quadtree, penjejakan gerakan secara Lagrangian telah dilaksanakan untuk mengkaji kesan berasingan dan kesan gabungan kedua-dua pembangunan di atas terhadap takdir jasad aliran. Keputusan menunjukkan bahawa pergerakan jasad amat bergantung kepada kitar air pasang surut dan posisi permulaan masing-masing. Pemanjangan jarak antara sekumpulan jasad telah diperhatikan dalam semua kes, manakala penyebaran jasad hanya berlaku di bahagian timur Selat Tebrau. Walaupun aliran keluar dari muara Sungai Johor dijangka meningkat selepas kedua-dua pembangunan berkenaan selesai, jangka masa tundaan pergerakan jasad di bahagian timur Selat Tebrau bertambah. Ini menunjukkan bahawa ada kemungkinan besar ancaman alam sekitar air kawasan tersebut yang sedia tercemar.

Kata kunci: Muara Johor; jejakan Langrangian; Selat Tebrau; Pulau Tekong

\section{INTRODUCTION}

Located in Malaysia, Johor River Waterworks (JRWW) is the largest potable water supply to Singapore, with a total output of $250 \mathrm{mgd}$ (UK gallons) (A-control 2014). Recently, Johor government has launched a project to construct a tidal barrage near Kota Tinggi across Johor River to prevent saline intrusion in Johor River Estuary (JRE) from reaching JRWW (Mohamad Salleh 2013) (see Figure 1 \& 2). Upon completion, the operation of the barrage will reduce the need of salinity flushing from Linggiu Dam upstream, thus lowering the average riverine discharge into the estuary.

Meanwhile, the infamous large-scale coastal reclamation at Tekong Island, Singapore at the confluence of JRE and East Tebrau Strait (ETS) had begun since late 1970s and is still in progress until present day (see Figure $1 \& 3$ ). Although earlier studies suggest that the impact of the proposed reclamation work on Malaysian water is negligible (Syamsidik \& Koh
2003; Syamsidik 2003; Koh \& Lin 2006), however, Lee and Zaharrudin (2014b) shows that local hydrodynamic is altered particularly due to the coupling effect of the reduced riverine discharge following the construction of the tidal barrage. Using a set of hyperbolic shallow water equations, solved on a quadtree grid system, Lee and Zaharruddin (2014b) compared the flow field in JRE and ETS before and after the reclamation works in Tekong Island, as well as after the completion of the tidal barrage in Kota Tinggi. It is shown that compared to the original condition, flow rate is greatly reduced in both JRE and ETS after the completion of both development schemes. This may cause reduced flushing effect which can have a negative impact on the environmental flow in the above water bodies, which are important locally as a source of aquatic produce. The effect can be detrimental to the local water quality which is already of great concern (Lee \& Zaharrudin 2014a). 


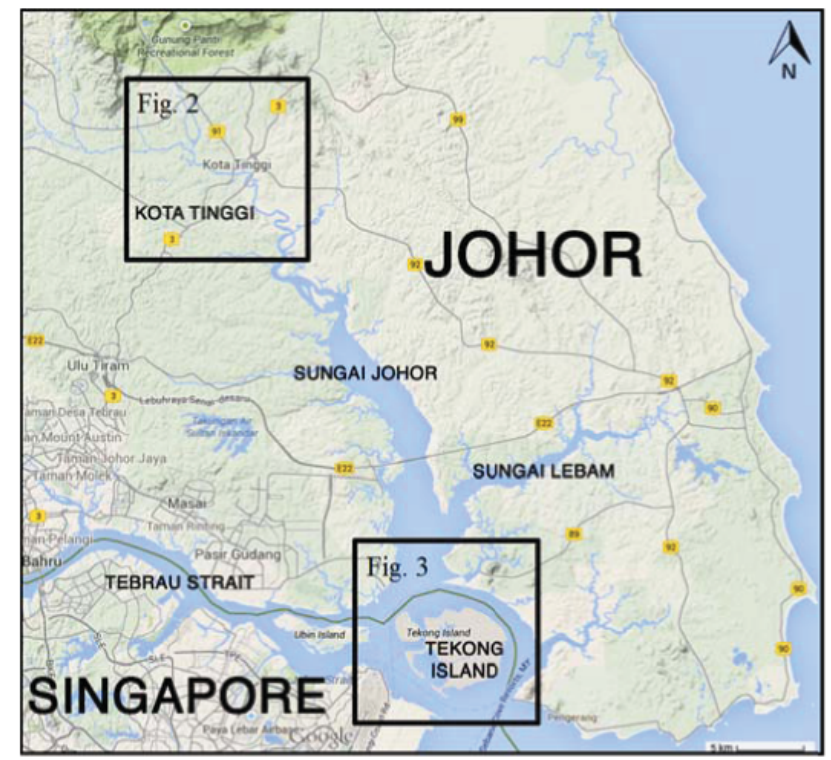

FIGURE 1. Johor River Estuary. Inset showing locations of Kota Tinggi (Figure 2) and Tekong Island (Figure 3) (Image taken from Google Map)



FIGURE 2. Location of the proposed tidal barrage in Kota Tinggi
In this paper, particle advection in JRE and ETS considering the flow fields presented by Lee and Zaharrudin (2014b) is presented. Passive tracers are released and tracked using Lagrangian approach to identify the trajectories, changes in separation distance, and residence time (escape rate) under typical spring and neap tidal conditions for three scenarios, namely before reclamation (Case 1), after reclamation (Case 2), after reclamation and completion of tidal barrage (Case 3).

\section{LOCATION OF STUDY}

The combined total catchment area of JRE and ETS is estimated at $2,636 \mathrm{~km}^{2}$, characterized mainly by natural forest and low land swamps in the northern and central area, and oil palm and rubber plantations at the south. Kota Tinggi is a mid-size township; urbanized landscape, meanwhile, stretches along the south coast from the state capital Johor Bahru to Pasir Gudang, a busy port with heavy industrial activities. Other than Johor River and the ETS, Lebam River and Santi River are amongst the other larger rivers that discharge into JRE (Figure 4). The average water depth in JRE and ETS is 6.5 $\mathrm{m}$ (Deltares et al. 2010), but ranges from as low as $1.0 \mathrm{~m}$ near the shore, and up to $16.9 \mathrm{~m}$ along the port navigational channel (Figure 5).

The estuarine hydrodynamic is dominated by the interaction between riverine discharge and the mixed, semidiurnal dominant tide (Lee 2007), with spring tidal range between $1.59 \mathrm{~m}$ to $4.21 \mathrm{~m}$, and neap tidal range between 2.34 $\mathrm{m}$ to $3.5 \mathrm{~m}$. Basin-wide mean annual rainfall of the area is estimated at $2470 \mathrm{~mm}$ (Shafie 2009). Johor River discharge is approximately $37.5 \mathrm{~m}^{3} / \mathrm{s}$ (Deltares et al. 2010), but data for other smaller rivers are not available. Analysis of catchment boundary (Figure 4) shows that the runoff are mainly from Johor River (54\%), followed by Lebam River (34\%), Tebrau River (7\%) and Santi River (5\%) (Deltares et al. 2010), with a combined total estimated at $69.0 \mathrm{~m}^{3} / \mathrm{s}$ under regular flow condition, assuming meteorological homogeneity.
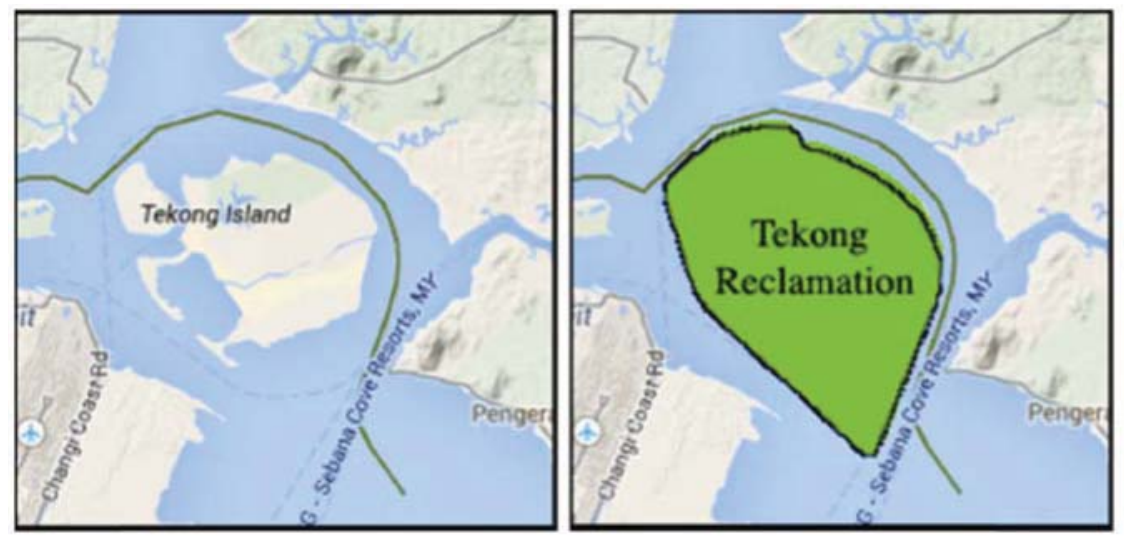

FIGURE 3. Tekong Island: before (left) and after (right) reclamation 


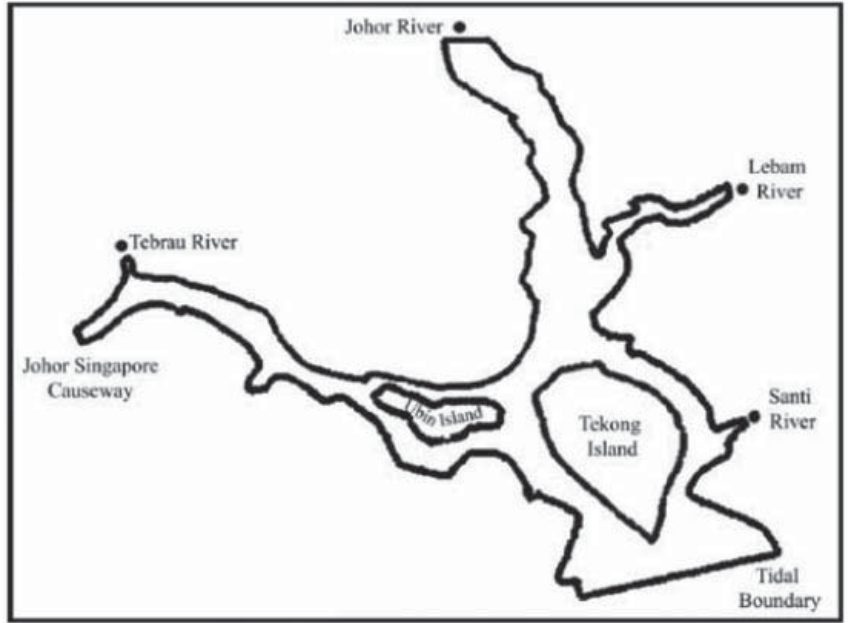

FIGURE 4. Computational domain, showing tidal open boundaries, and locations of river inlet $(\bullet)$

FLOW FIELD SIMULATION AND VALIDATION

The flow field is computed using two-dimensional depthaveraged shallow water equations in the form of a nonhomogenous hyperbolic system with source term (Lee \& Zaharrudin 2014b; Lee 2011) (see Appendix). The system solves up to second order all equilibria solutions, and is discretised using Cartesian coordinate system on a set of quadtree grid capable of local refinement, which better approximate the complex boundary and any specific region of interest (Figure 6) (Rogers et al. 2001; Liang et al. 2004). Simulation is ramped up using the river discharges, and then superpose with the tidal effect considering 4 main tidal constituents (O1, K1, M2 and S2). The resulting water level fluctuation is verified against the records of tidal water level at JUPEM tidal station 48484 at Jeti Kastam, Johor Bharu $\left(1^{\circ} 27^{\prime} 42^{\prime \prime} \mathrm{N}, 103^{\circ} 47^{\prime} 30^{\prime \prime} \mathrm{E}\right)$ (Figure 7). In addition, simulated flow velocities sampled at Johor River (P), Tebrau Strait (Q), Tekong East (S), and Tekong West (R) (see Figure 6) are found to agree well with reported field observations at these

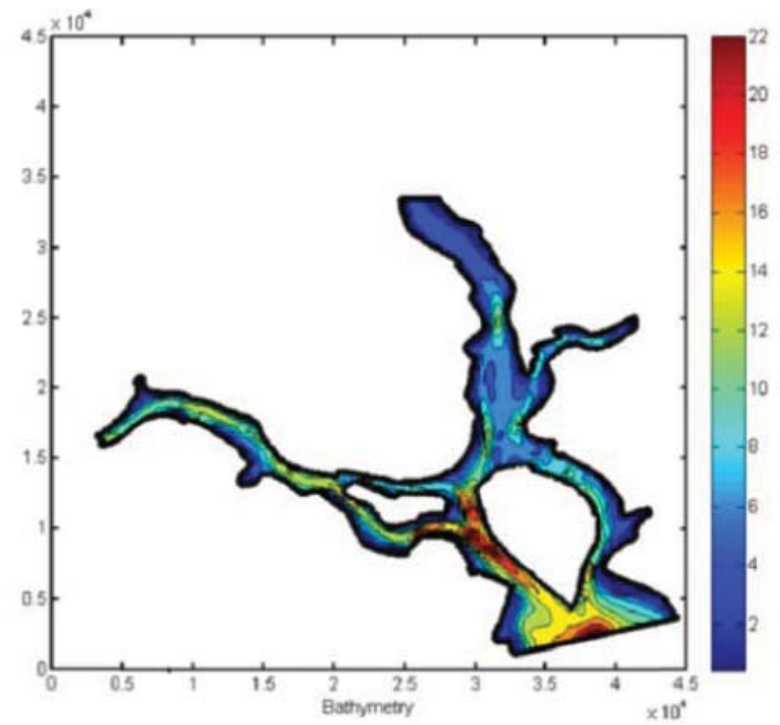

FIGURE 5. Bathymetry of Johor River estuary (JRE) and East Tebrau Strait (ETS)

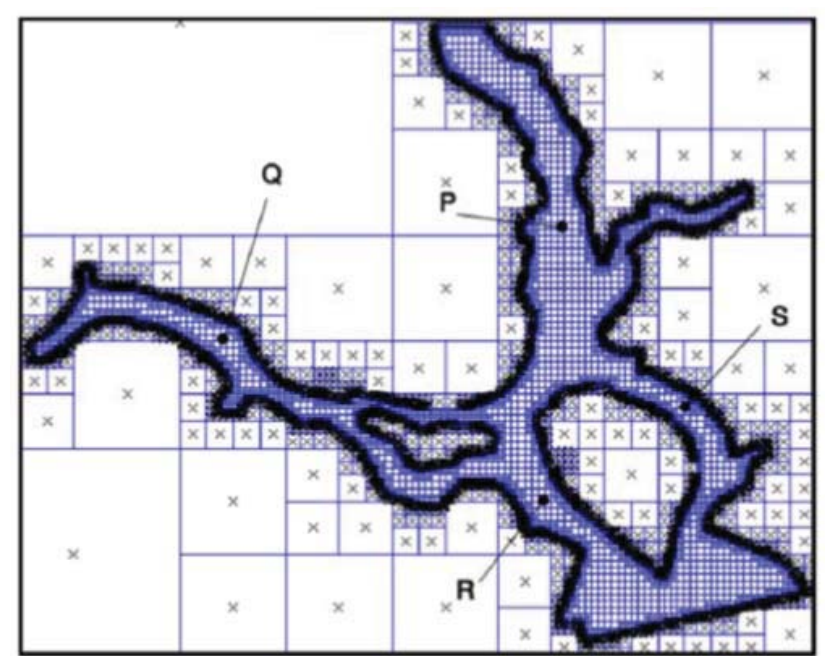

FIGURE 6. Quadtree computational grid. Note that the noncomputational cells are marked ' $\times$ '. Also showing initial positions $\mathrm{P}, \mathrm{Q}, \mathrm{R}$ and $\mathrm{S}$ for particle tracking

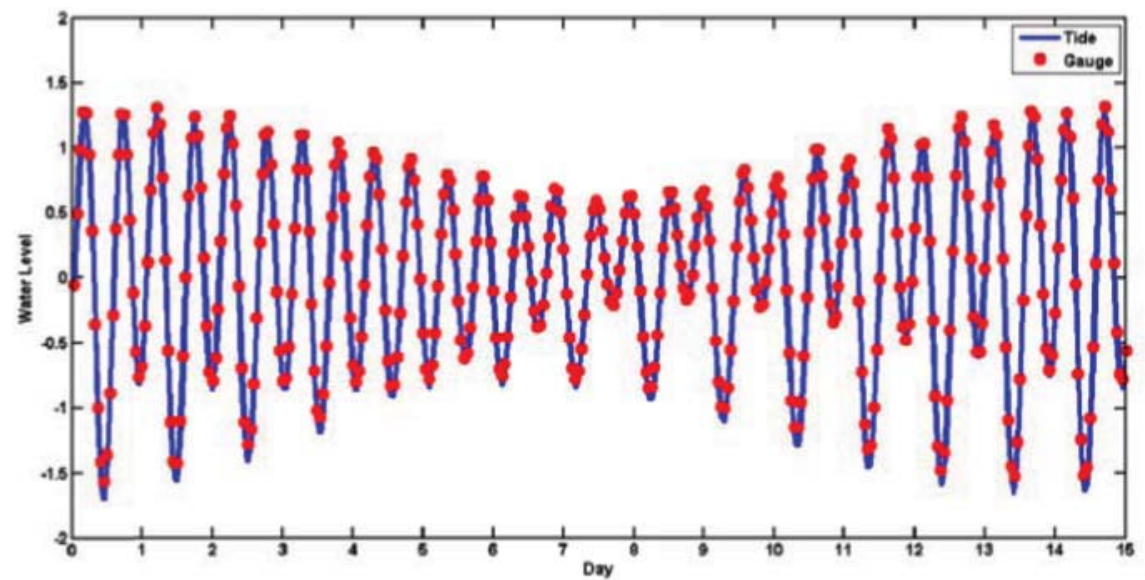

FIGURE 7. Simulated and observed water level fluctuation at JUPEM tidal station 48484 
locations (Lee \& Zaharuddin 2014a). Overall, the effect of the reclamation works at Tekong Island causes flow acceleration around it (Point R and S), whereas reduced flow velocities are observed in JRE and ETS (Point P and Q, respectively) (Lee \& Zaharuddin 2014b).

\section{LAGRANGIAN PARTICLE TRACKING}

The advection equation in a two-dimensional Cartesian coordinate system is expressed as

$$
\frac{\mathrm{d} x}{\mathrm{~d} t}=u(x, y, t), \frac{\mathrm{d} y}{\mathrm{~d} t}=v(x, y, t),
$$

where $(x, y)$ is the position of a given particle with respect to an arbitrary origin at time $t ; u$ and $v$ denote the Eulerian velocity components in the $x$ - and $y$-directions of the flow respectively at the same spatial and temporal point as the particle (Liang et al. 2006a, 2006b). Time-integration of the advection equations is performed using a Runge-Kutta Cash-Karp algorithm on the Eulerian velocity field obtained in the preceding section.

Ignoring diffusion for a relatively large scale shallow water flow in the present problem, a typical tidal day (24 h) under spring or neap tidal condition is represented using 96 SETS of instantaneous flow fields sampled at equal intervals of 15-min. These flow fields are then looped to produce the cyclic flood and ebb conditions (Lee et al. 2014). Continuous velocity field is interpolated linearly across adjacent cells, but assume unchanged within the 15 -min time window. Essentially, the advection of the passive particles is examined using a simple time-periodic flow of the domain.

For the study of particle fate, a set of 10,000 particles arranged in a square grid with an initial separation of $2 \mathrm{~m}$ between adjacent particles along the $x$ - and $y$-directions is deployed at specific initial positions within the computational domain. The trajectories, the separation distance, and the escape time of the particles are compared for different initial positions, and under spring and neap tidal conditions.

\section{RESULTS AND DISCUSSIONS}

\section{PARTICLE TRAJECTORIES}

Observations of particle trajectories are very similar for the scenario prior to reclamation in Tekong Island (Case 1), after reclamation but before the construction of tidal barrage in Kota Tinggi (Case 2), and when both the reclamation works and proposed tidal barrage are completed (Case 3). In this section, qualitative descriptions of the particle trajectories are presented. The objective differences in all 3 cases will be examined in the subsequent section.

First, the particle trajectories released at position $\mathrm{P}$ in JRE under spring and neap tidal conditions is examined. The initial position is predominantly influenced by the discharge of Johor River. However, as particles travel south, the effect of Lebam River discharge from the east causes the trajectory to eventually tend towards the west of Tekong Island (Figure 8). It is noted that the relative strength of Lebam River discharge is more than half that of the southward discharge of Johor River (34\% compared to Johor River's 54\% of estuary-wide discharge respectively, see Section 2), and thus constitutes a major forcing that dictates the fate of tracer approaching the confluence. It is observed that particle advection is very similar for both spring (Figure 8a) and neap (Figure 8b) tidal conditions. This is owing to the fact that the average flow velocity in JRE at position $\mathrm{P}$ is dominated by river discharge and approximates an average of $2 \mathrm{~m} / \mathrm{s}$ regardless of the tidal cycle (Lee \& Zaharuddin 2014a). The particles approach the southern tip of Tekong Island towards to end of $4 \mathrm{~h}$ in both cases and begin to exit the domain shortly thereafter. Along the journey, the original square patch of particles is increasingly stretched and elongated with little dispersion, but shows sign of recoup shortly prior to its exit from the domain. The process can be attributed to the alternating tidal forcing which acts with or against the constant river discharge at different time of the cycle.

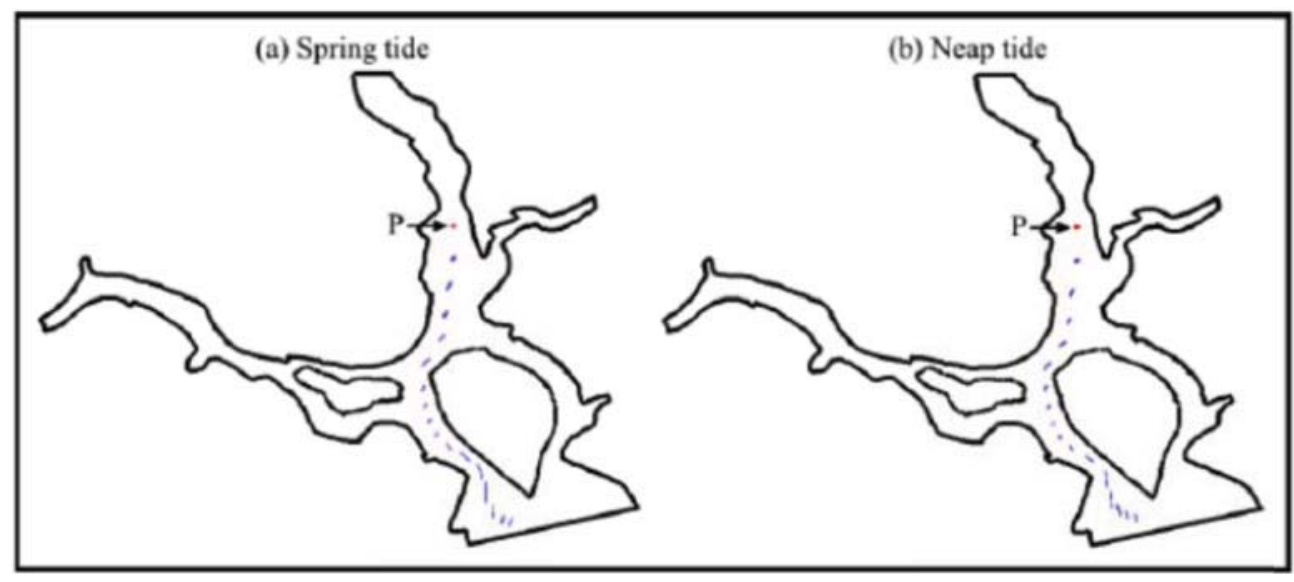

FIGURE 8. Particle advection in JRE under (a) spring, and (b) neap tide. Plots show initial position at $\mathrm{P}$, and successive particle positions at 15 -min intervals up to $t=4 \mathrm{~h}$ 
Particles released at position Q in ETS, however, show significantly different fate compared to the preceding case. Figure 9 and 10 shows the advection and dispersion of the original square patch of 10,000 particles as they traverse the ETS eastward. Particle movement is much slower compared to those in JRE, at about $1 / 10^{\text {th }}$ the average velocity of JRE (Lee \& Zaharuddin 2014a), resulting in close proximity of particle positions in the 15-min interval plotted.

For spring tide condition (Figure 9), the leading particles reached Ubin Island after $6 \mathrm{~h}$ (Figure 9a) and tend to move towards the south of the island. At the end of $12 \mathrm{~h}$ (Figure $9 \mathrm{~b}$ ), these particles reached the eastern-most tip of Ubin Island. When the particles approaches Tekong West region, the movement accelerated due to the larger flow velocity adjacent to Tekong Island (Lee \& Zaharuddin 2014b). As a result, particles begin to escape from the domain within the next $6 \mathrm{~h}$ (Figure 9iii). It is worth noting that these particles tend to traverse along the coast of Singapore and do not enter into the south-moving bulk flow from Johor River.

Under neap tide condition (Figure 10), particle advection demonstrates less dispersion, though same order of stretching can be observed within the first $6 \mathrm{~h}$ (Figure 10a). As opposed to spring tide condition, comparable number of particles moves toward the north and the south of Ubin Island after $6 \mathrm{~h}$ (Figure 10b). It is observed that particles north of Ubin Island tend to get washed along the shore. Particles south of the island eventually leave the nearshore region of Ubin Island, and begin to approach Tekong West at the end of $18 \mathrm{~h}$ (Figure 10iii).

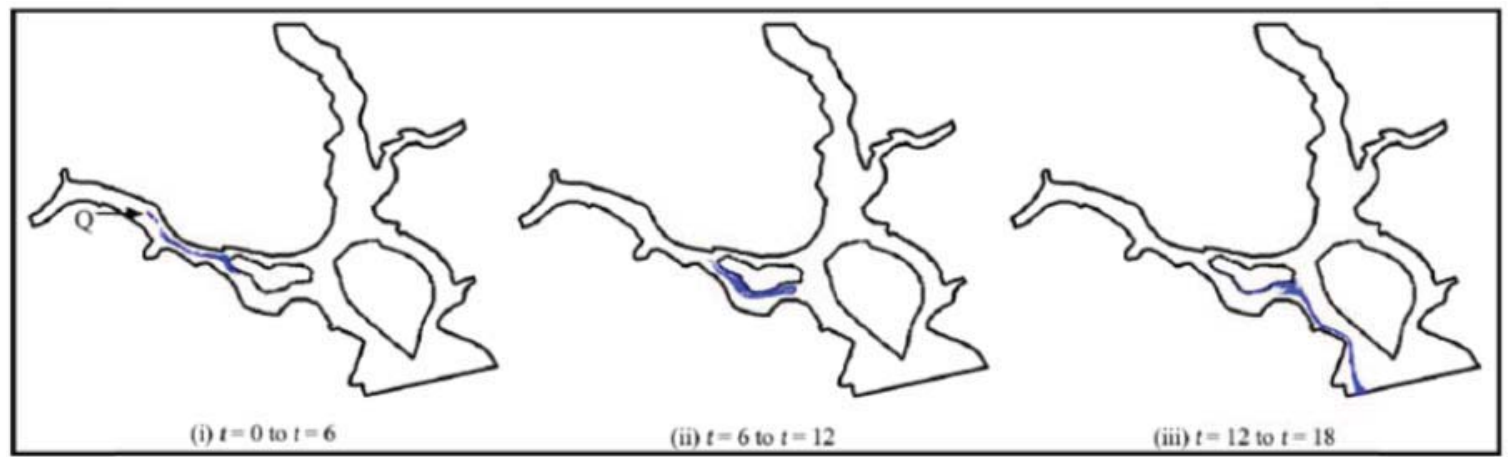

FIGURE 9. Particle advection in ETS under spring tide. Plots show the successive particle positions at 15-min intervals for (i) $t=0-6 \mathrm{~h}$, (ii) $t=6-12 \mathrm{~h}$, (iii) $t=12-18 \mathrm{~h}$. The initial position Q is as indicated in (i)

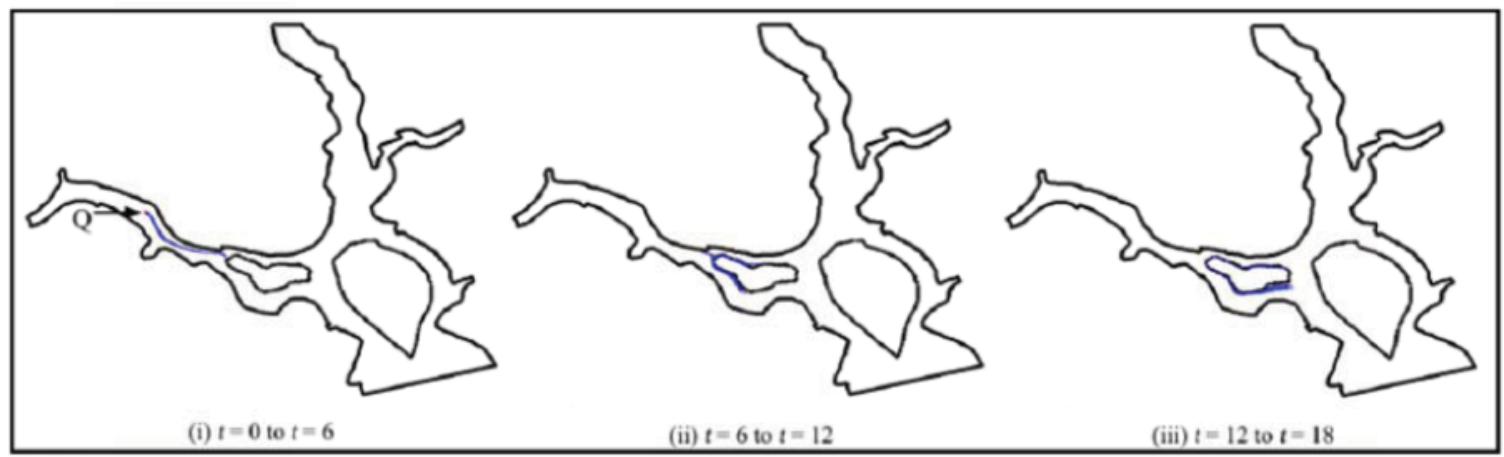

FIGURE 10. Particle advection in ETS under neap tide. Plots show the successive particle positions at 15-min intervals for (i) $t=0-6 \mathrm{~h}$, (ii) $t=6-12 \mathrm{~h}$, (iii) $t=12-18 \mathrm{~h}$. The initial position Q is as indicated in (i)

Particles deployed at position $\mathrm{R}$ and $\mathrm{S}$, to the west and east of Tekong Island, respectively, are promptly flushed out of the domain due to the relatively high velocities around the island (figures not shown), and will not considered further in the subsequent discussions.

\section{STATISTICAL PROPERTIES}

In this section, the temporal variation of mean and standard deviation of neighbouring particle distance are examined. The spring (Figure 11) and neap (Figure 12) tide conditions are considered for all 3 cases, with initial positions at (a) Johor River (P), and (b) Tebrau Strait (Q).

Comparing Figure $11 \mathrm{a}$ with $11 \mathrm{~b}$, and $12 \mathrm{a}$ with $12 \mathrm{~b}$, it can be observed that the mean distance and standard deviation between particles is relatively small for particles released in the Johor River compared to particles released in Tebrau Strait. This is in good agreement with the results shown in Figure 8-10, where particles released in Johor River is 
advected mainly as a patch, whereas particles released in Tebrau Strait undergo substantial dispersion.

For particles released in Johor River, the mean and standard deviation of particle distance does not exceed $6 \mathrm{~m}$ generally after 1 hour regardless spring (Figure 11a) or neap tide (Figure 12a) conditions.

For particles released at Tebrau Strait, the mean and standard deviation of particle distance during neap tide (Figure 12b) is in the same order as that observed for the particles released at Johor River. However, during spring tide, the mean particle distance after 1 hour exceeds $15 \mathrm{~m}$ in Case 2, and is over $25 \mathrm{~m}$ in Case 1 (Figure 11b). Meanwhile, the standard deviation also increases to $16 \mathrm{~m}$ (Case 2) and $42 \mathrm{~m}$ (Case 1) respectively. The only exception is Case 3 which is not significantly affected by the spring tide.

The observations above suggest that the reclamation work in Tekong Island (Case 2) and the tidal barrage in Kota
Tinggi (Case 3) reduce particle dispersion in Tebrau Strait during spring tide considerably (Figure 11b). Meanwhile for spring tide condition in Johor River (Figure 11a), the reclamation work (Case 2) results in accelerated flow and thus dispersion, measured in terms of mean and standard deviation of particle distance here, increased marginally. Nevertheless, the proposed tidal barrage in Kota Tinggi (Case 3) reverse the effect, causing dispersion to reduce overall compared to the original (Case 1) condition. The effects of the two developments are however not evident during neap tidal cycle (Figure 12).

It is noted that the present measurement take into consideration absolute distance between particles only. Referring to Figure 8-10, it is evident that longitudinal stretching contributes more than dispersion in the lateral direction. (i)

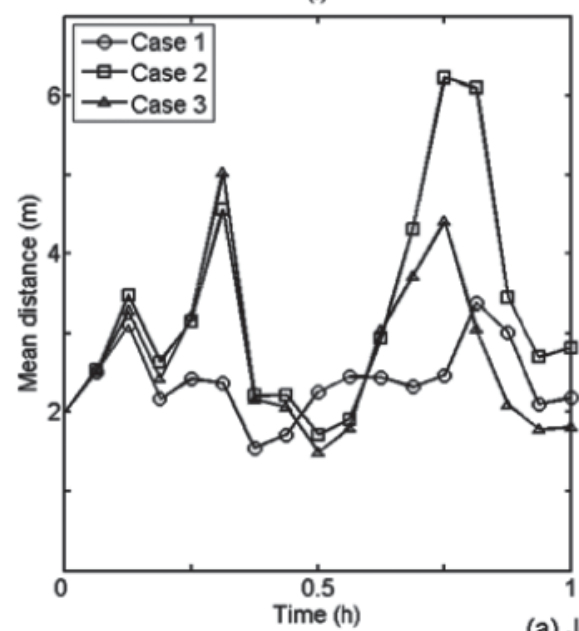

(a) Johor River, $\mathrm{P}$ (ii)

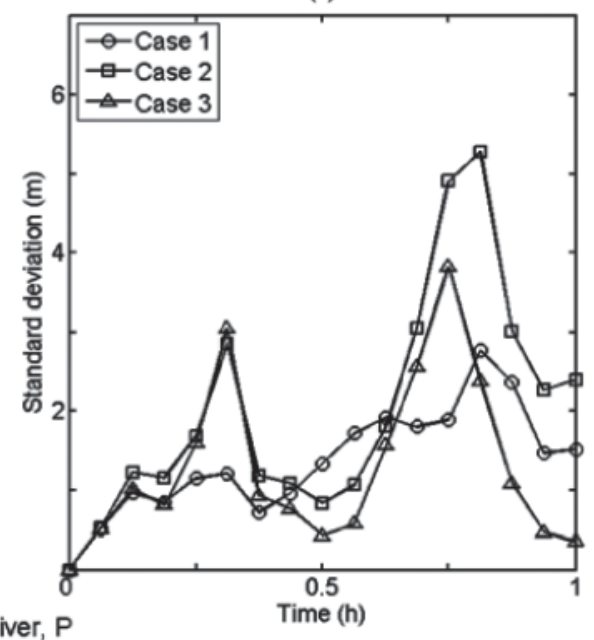

(ii)

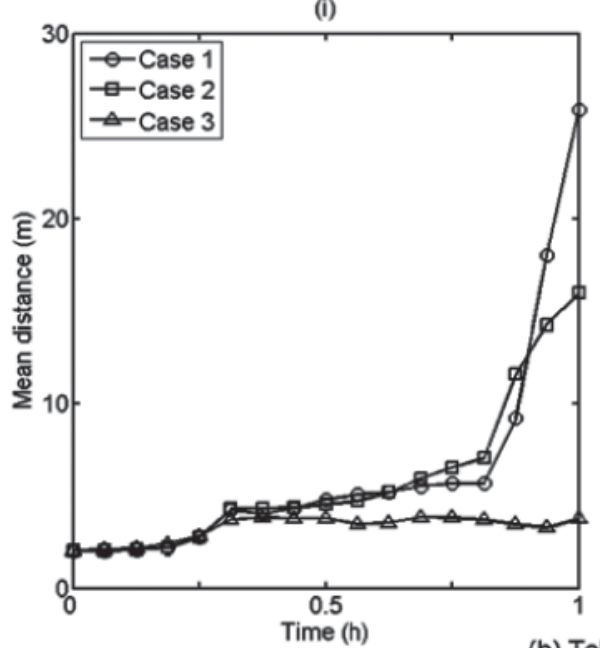

(b) Tebrau Strait, $\mathrm{Q}$

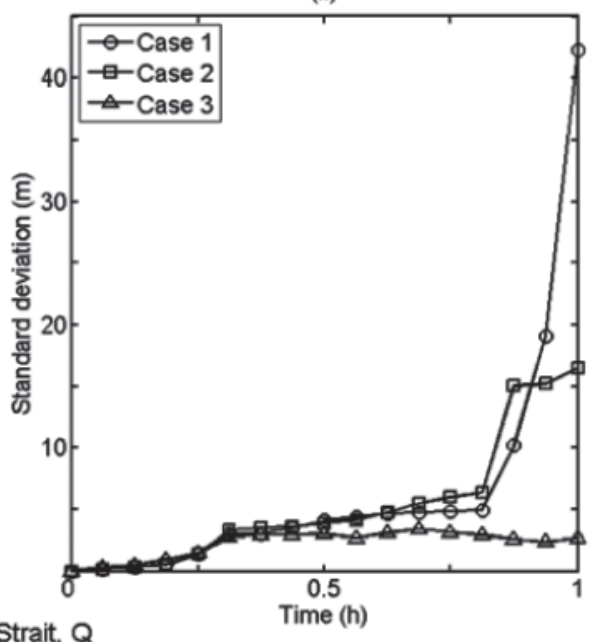

FIGURE 11. Temporal variation of (i) mean, and (ii) standard deviation of particle distance under spring tide for Case 1 - 3. Initial positions (a) P, and (b) Q respectively 


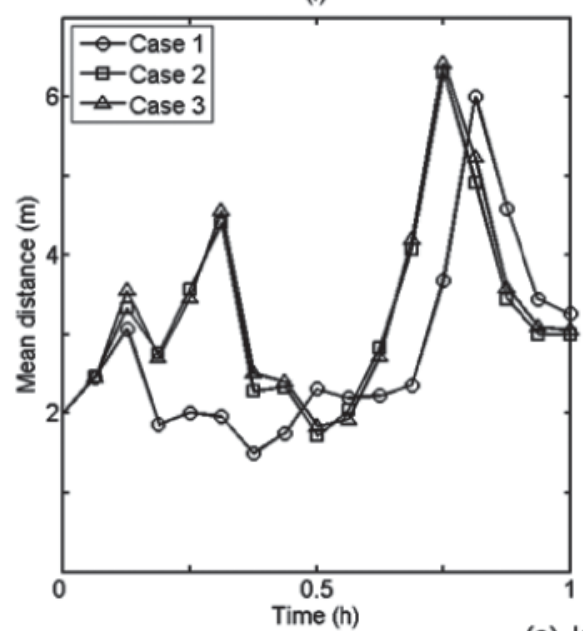

(a) Johor River, $\mathrm{P}$

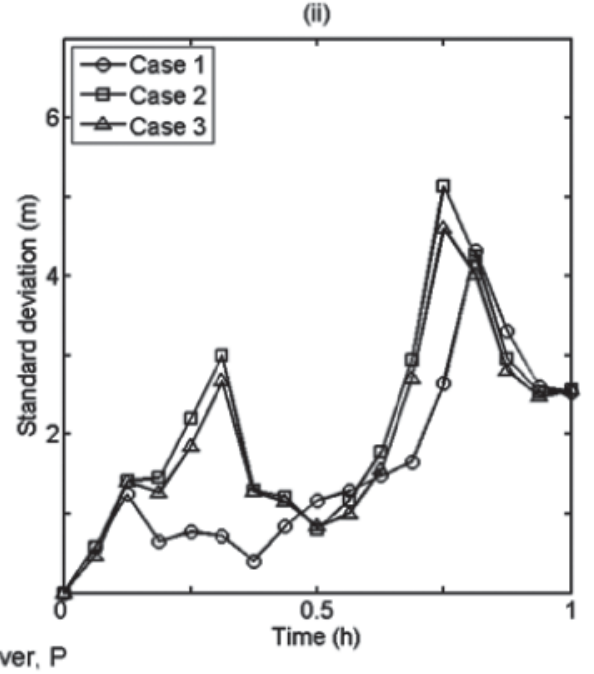

(ii)

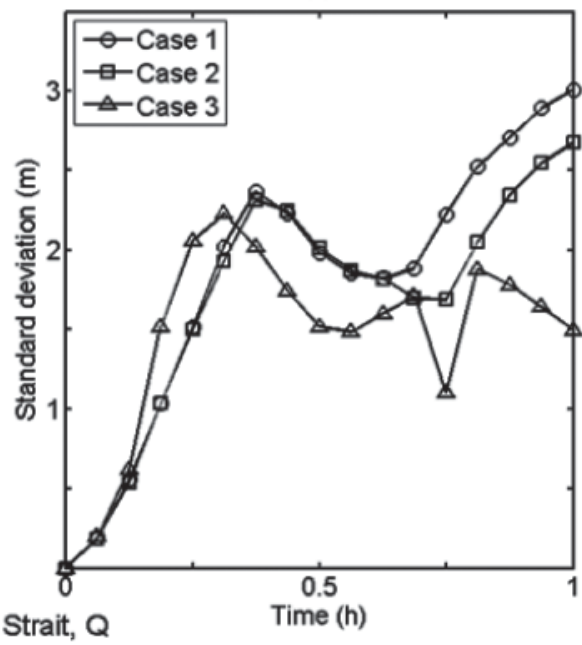

FIGURE 12. Temporal variation of (i) mean, and (ii) standard deviation of particle distance under neap tide for Case $1-3$. Initial positions (a) P, and (b) Q respectively

\section{PARTICLE ESCAPE TIME}

Figure 13 shows the particle count in the domain for all 3 cases, under spring and neap tide conditions when released at position P (in JRE) and Q (in ETS), respectively. Particles released at $\mathrm{P}$ only begins to exit the domain well after $4 \mathrm{~h}$ and escape promptly, in both spring and neap tide such that no particle is left within the next $1 \mathrm{~h}$ (Figure 13a(i) \& b(i)). This indicates that all the particles are in close proximity with one another, and is in good agreement with the observations in Figure 8 . The only exception is Case 1 for neap tide, where particle escape occurs much later beyond $6 \mathrm{~h}$. Meanwhile particles released at $\mathrm{Q}$ only begin to exit the domain after 6 h (Figure 13a(ii) \& 13b(ii)) under both spring and neap tide. Particle escape takes much longer time, and the number of particles remaining shows staircase reduction behavior due to flushing effect during ebb tide. All particles escaped after $18 \mathrm{~h}$ for spring tide condition (Figure 13a(ii)), but took longer for neap tide condition (Figure 13b(ii)).
Figure 14 summarizes the particle resident times in the computational domain. Resident times are generally higher under neap tide condition. For particles released at $\mathrm{P}$, the resident time is close to half or even less compared to those released at Q. For particles released at P, Case 2 and Case 3 reduce the resident time of particles within the domain, suggesting higher escape rate after the completion of reclamation work in Tekong Island and the construction of the tidal barrage in Kota Tinggi. On the other hand, both Case 2 and Case 3 scenarios increase resident time of particles released at Q. In conclusion, the proposed developments are likely to further aggravate the water quality in ETS although the impact to JRE may not be significant.

\section{CONCLUSIONS}

The flow field in Johor River Estuary (JRE) and East Tebrau Straits (ETS) are simulated using shallow water model solved on hierarchical adaptive grid, and verified against observed 

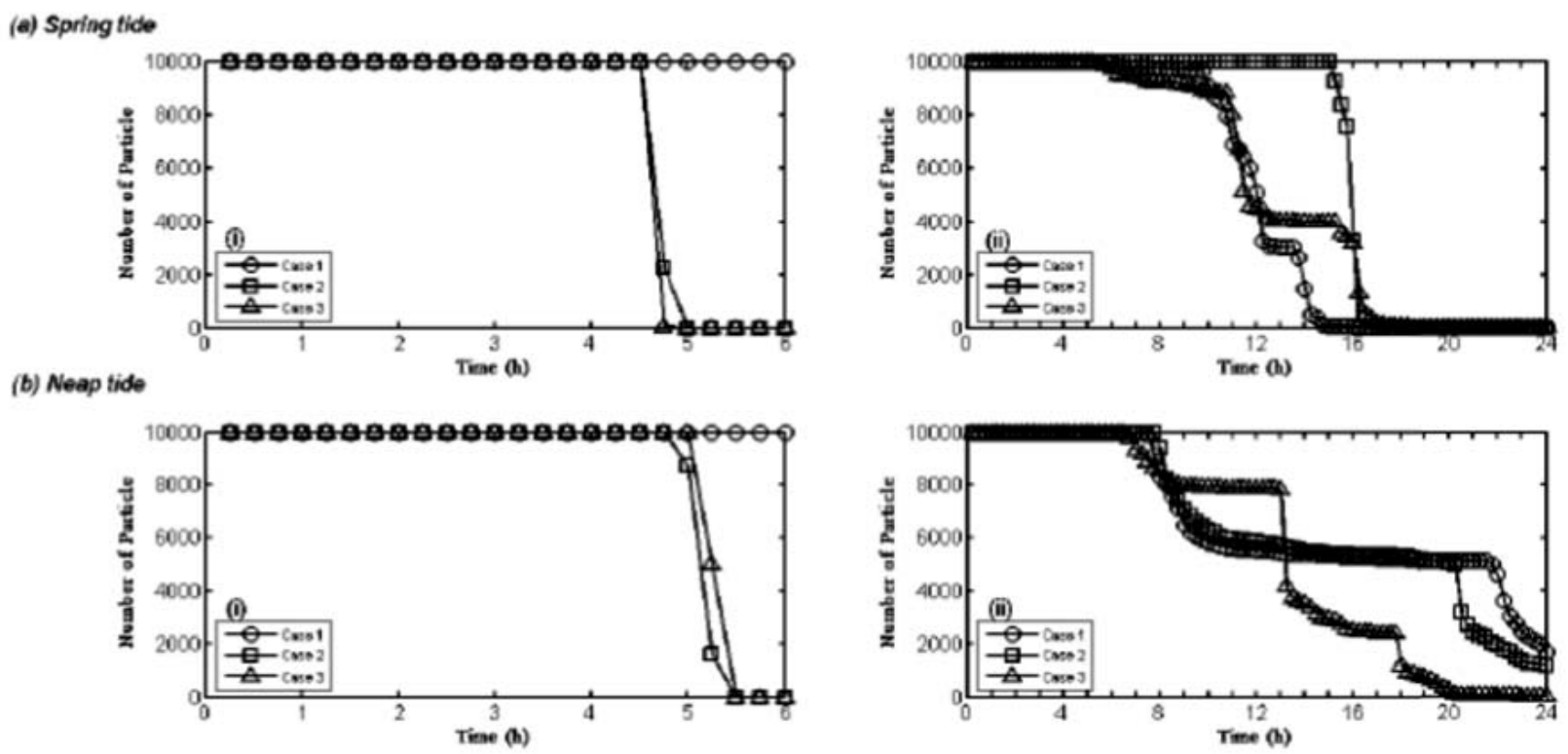

FIGURE 13. Residual particle number under (a) spring and (b) neap tide, for initial particle positions at (i) P, and (ii) Q, respectively
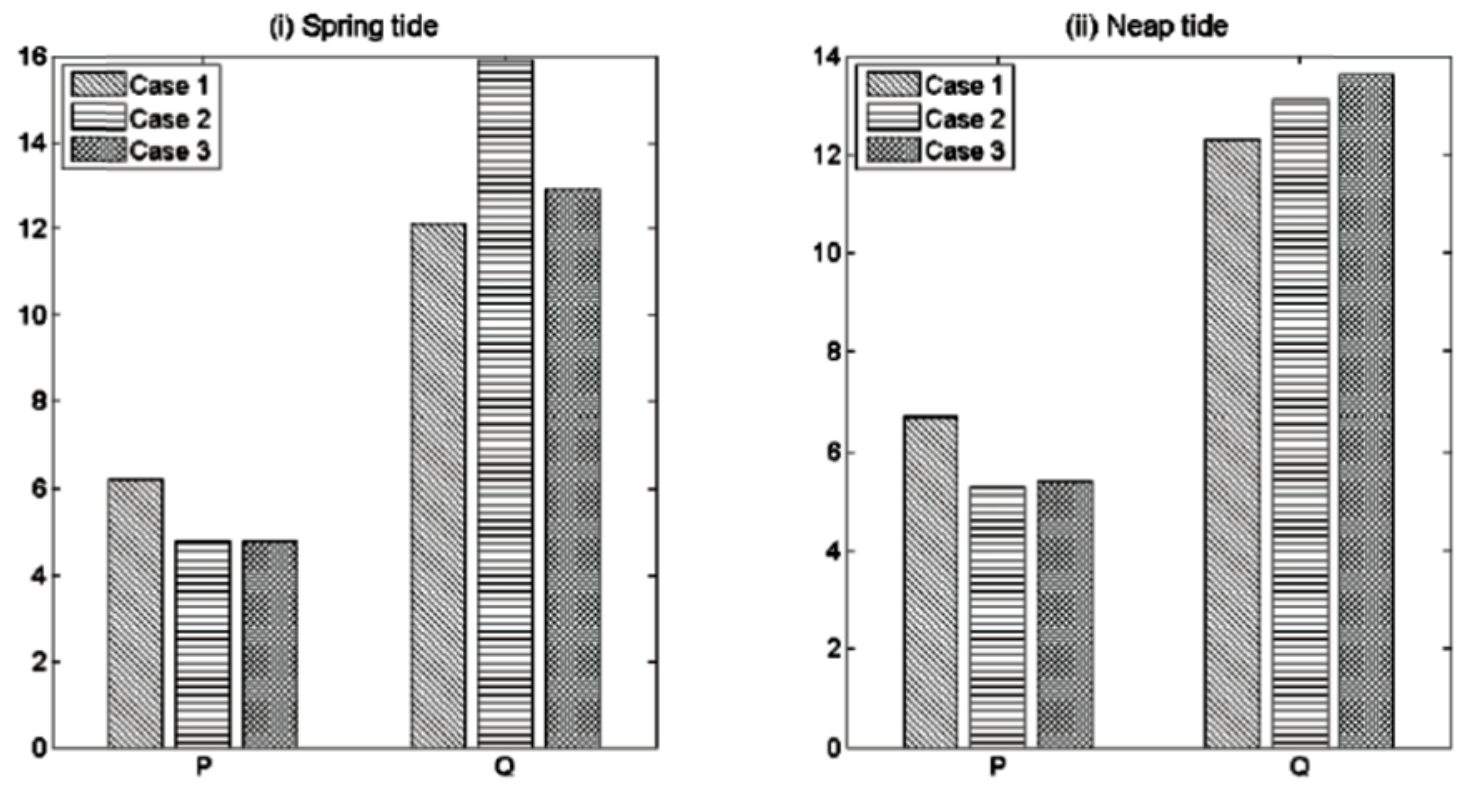

FIGURE 14. Particle resident time for Case $1-3$ under (a) spring, and (b) neap tide

water level and known flow velocities. Three scenarios are considered in the present study: Case 1 represents the original domain prior to the reclamation works in Tekong Island, Case 2 represents the condition after the completion of the reclamation works, and Case 3 represents the condition after both the reclamation works and the proposed tidal barrage in Kota Tinggi are completed. Using Lagrangian technique, the trajectories, statistical properties and escape time of particles released at both JRE and ETS are examined. It is shown that in addition to the initial position, the tidal cycle is important in the flushing of particles out of the domain. Particle resident time reduces in JRE but increases in ETS under Case 2 and
Case 3 scenarios, suggesting that the two developments have overall negative impact to the water quality in ETS.

\section{ACKNOWLEDGEMENT}

The authors gratefully acknowledge the support provided by the Ministry of Higher Education Malaysia (FRGS/1/2012/ TK03/UiTM/03/6), and Research Management Institute (RMI) of Universiti Teknologi MARA. 
REFERENCES

A-control \& i. Johor River Waterworks. 2014. Retrieved on: 2 October 2014. http://www.a-control.com.sg/ index.php/ showcase-project/johor-river-water-works.

Deltares, Imares \& Boskalis. 2010. Project SI 4.1 - phase 2: A quick-scan of literature and available numerical models. Report, prepared for EcoShape.

Koh, T. \& Lin, J. 2006. The land reclamation case: thoughts and reflections. Singapore Year Book on Int. Law \& Contributors X: 1-7.

Lee, W. K. 2007. Long-term tidal forecasting and hindcasting using QuickTIDE Tidal Simulation Package. IEM Journal 68(2): 58-64.

Lee, W. K. 2011. Chaotic mixing in wavy-type channel and two-layer shallow flows. DPhil Thesis, Engineering Science. University of Oxford.

Lee, W. K. \& Zaharuddin, N. A. 2014a. Hydrodynamic model for the investigation of environmental flow in Johor River Estuary. Int. Civil Infrastruct. Eng. Conf. (InCIEC), Kota Kinabalu, Sep 28 - Oct 1, 2014. IIESM, UiTM: 373-385.

Lee, W. K. \& Zaharuddin, N. A. 2014b. Hydrodynamic investigation on the compound effects of reclamation work and proposed tidal barrage on Johor River estuary and East Tebrau Strait. Int. Conf. Civil Eng. Building Mat. CEBM, Hong Kong, 23-24 Nov 2014. IASHT/ ISERC.

Lee, W. K., Borthwick, A. G. L. \& Taylor, P. H. 2014. Tracer dynamics in two-layer density-stratified estuarine flow. Proc. ICE - Eng. Comput. Mech.UK 167(1): 41-49.

Liang, Q., Borthwick, A. G. L., Stelling, G. 2004. Simulation of dam- and dyke-break hydrodynamics on dynamically adaptive quadtree grids. Int. J. Numer. Methods Fluids 46: $127-162$.

Wei-Koon Lee*

Fluvial \& River Engineering Dynamics Group (FRiEnD)

Faculty of Civil Engineering

Universiti Teknologi MARA

40450 Shah Alam, Selangor

Malaysia

Nur Hidayah Aqilla binti Zaharuddin

Reseach student, Faculty of Civil Engineering

Universiti Teknologi MARA, 40450 Shah Alam

Selangor, Malaysia.

*Corresponding author; email: weikoon2004@yahoo.com

Received date: $28^{\text {th }}$ November 2014

Accepted date: $30^{\text {th }}$ March 2015
Liang, Q, Borthwick, A. G. L. \& Taylor, P. H. 2006a. Windinduced chaotic advection in shallow flow geometries. Part I: Circular basins. J. Hydraul. Res. 44(2): 170179.

Liang, Q, Borthwick, A. G. L. \& Taylor, P. H. 2006b. Windinduced chaotic advection in shallow flow geometries. Part II: Non-circular basins. J. Hydraul. Res. 44(2): 180-188.

Malaysian Coastal Resources Study Team, Ministry of Science, Technology and the Environment. 1992. The coastal resources management plan for South Johore, Malaysia. ICLARM Technical Report on Coastal Area Management 33: 144.

Mohamad Salleh, H. 2013. Construction of Sungai Johor barrage Kota Tinggi, Johor. Water Supply Department, Ministry of Energy, Green Technology and Water. Retrieved on: 2 October 2014. http://www.jba. gov.my/index.php/en/rujukan/technical-papers/537construction-of-sungai-johor-barrage-kota-tinggijohor.

Rogers, B. D., Fujihara, M. \& Borthwick, A. G. L. 2001. Adaptive q-tree Godunov-type scheme for shallow water equations. Int. J. Numer. Methods Fluids 35: 247-280.

Shafie, A. 2009. Extreme Flood Event: A case study on floods of 2006 and 2007 in Johor, Malaysia. MSc Thesis. Colorado State University.

Syamsidik \& Koh, H. L. 2003. Impact assesment modeling on coastal reclamation at Pulau Tekong. Integrating Technology in the Mathematical Science: 1-8.

Syamsidik. 2003. Singapore coastal reclamation: History and problems. Academic Seminar of Indonesian Students Association: 1-7. 
APPENDIX

Two-dimensional depth-averaged shallow water equations in the form of a non-homogenous hyperbolic system (Lee 2011) is considered:

$$
\mathrm{W}_{t}+\mathrm{A}_{\mathrm{F}}(\mathrm{W}) \mathrm{W}_{x}+\mathrm{A}_{\mathrm{G}}(\mathrm{W}) \mathrm{W}_{y}=S \text {. }
$$

where that the subscripts $x, y$ and $t$ denote partial derivatives with respect to the $x$-direction, $y$-direction, and time respectively. The vector of unknowns, $\mathrm{W}$, is defined as

$$
\mathrm{W}=\mathrm{W}(x, y, t)=\left[h, q_{x}, q_{y}\right]^{T},
$$

where $h$ is the water depth, $q_{x}(x, y, t)$ and $q_{y}(x, y, t)$ are the flow rates in the $x$ - and $y$-directions respectively.

The system matrix of the quasilinear Equation 1 has the form of:

$$
\mathrm{A}(\mathrm{W})=\left[\begin{array}{cc}
\mathrm{A}_{\mathrm{F}}(\mathrm{W}) n_{x} & 0 \\
0 & \mathrm{~A}_{\mathrm{G}}(\mathrm{W}) n_{y}
\end{array}\right],
$$

where $\mathrm{n}=\left(n_{\mathrm{x}}, n_{\mathrm{y}}\right)$ is the unit vector, and $\mathrm{A}_{\mathrm{F}}$ and $\mathrm{A}_{\mathrm{G}}$ are the Jacobian matrices given by:

$$
\begin{aligned}
& \mathrm{A}_{\mathrm{F}}(\mathrm{W})=\frac{\delta \mathrm{F}}{\delta \mathrm{W}}\left[\begin{array}{ccc}
0 & 1 & 0 \\
c^{2}-u_{x}^{2} & 2 u_{x} & 0 \\
-u_{x} u_{y} & u_{y} & u_{x}
\end{array}\right], \\
& \mathrm{A}_{\mathrm{G}}(\mathrm{W})=\frac{\delta \mathrm{F}}{\delta \mathrm{W}}\left[\begin{array}{ccc}
0 & 0 & 1 \\
-u_{x} u_{y} & u_{y} & u_{x} \\
c^{2}-u_{x}^{2} & 0 & 2 u_{y}
\end{array}\right],
\end{aligned}
$$

where $c^{2}=g h$, and $g$ is the gravity acceleration. Here, the flux function vectors, $F$ and $G$ are defined as:

$$
\begin{aligned}
& \mathrm{F}=\mathrm{F}(x, y, t)=\left[\begin{array}{c}
q_{x} \\
q_{x}^{2} / h+g h^{2} / 2 \\
q_{x} q_{y} / h
\end{array}\right], \\
& \mathrm{G}=\mathrm{G}(x, y, t)=\left[\begin{array}{c}
q_{y} \\
q_{x} q_{y} / h \\
q_{y}^{2} / h+g h^{2} / 2
\end{array}\right] .
\end{aligned}
$$

The source term vector, $\mathrm{S}$ on the right-hand-side of Equation 1 is given by:

$$
\mathrm{S}=\mathrm{S}(x, y, \mathrm{~W})=\left[0, g h \frac{\mathrm{d} z}{\mathrm{~d} x}, g h \frac{\mathrm{d} z}{\mathrm{~d} y}\right]^{T},
$$

where $z$ is the bed elevation.

Solution of the system of equation requires the system matrices (4) and (5) to be non-singular. Following the approach of (Lee 2011; Chacon-Rebollo et al. 2003), a viscous correction term is added to Equation 1 to balance the diffusion term in the system. The equivalent system is then be tuned in such a way that any centered approximation (in space) will solve up to second order all equilibria solutions, and thus of the original system. 